IV. DEFINING COMMUNITIES, LANGUAGES, AND VARIETIES AND IDENTIFYING CONTACT-INDUCED INFLUENCES 
Journal of language contact - THEMA 3 (2010)

www. jlc-journal.org 


\title{
LANGUAGE AND IDENTITY IN FLUX: IN SEARCH OF BAÏNOUNK*
}

\author{
Friederike Lüpke
}

\author{
School of Oriental and African Studies, University of London
}

Endangered Languages Academic Programme,

\section{Introduction}

\subsection{The challenge: identifying the object of study}

All descriptive and documentary linguists are faced with a fundamental challenge: in order to reduce their object of enquiry to a manageable entity, they need to trim down the amount of variation present in spoken language by identifying at least some discrete entities. For linguists working on well-described languages, which tend to have written standards and agencies enforcing them, it is often possible to circumvent this problem by implicitly or explicitly focussing on the standard variety and/or partly stereotyped varieties. For field linguists, the problem has not been taken care of by political decisions, historical developments and the homogenising forces of modern mass media; they often encounter situations in which they face a daunting degree of variation in languages/varieties/lects that are closely related. This variation may occur in the speech production of individuals (intraspeaker variation or of different speakers (inter-speaker variation) in one discernable variety, or it may concern variation in linguistically related codes, often without clear boundaries created by extralinguistic factors. Thus, there may be small variations in the linguistic code that one might want to describe as dialectal variation, but the reference point may be unclear, and isoglosses might reveal different boundaries if they can be unambiguously identified in the first place. There may be no cut-off points from which onwards a variety is too distinct to be included under the umbrella of a given a language (the divergent and competing criteria for identifying a language notwithstanding). This already complex issue is further complicated by

\footnotetext{
* The research reported in this paper was made possible by a pilot project grant from the Endangered Languages Documentation Project (ELDP) and by research leave funded by the British Arts and Humanities Research Council (AHRC), whose support is gratefully acknowledged. I am equally indebted to the Bureau d'Organisation, de Recherche et d'Étude du Patrimoine Baïnounk (BOREPAB) in Senegal and to the Baïnounk Gunyaamolo community in the villages of Niamone and Diengué. I thank my main consultants Alpha Yaya Coly and Hamidou Coly for their contribution and comments.
} 
the fact that small minority languages without a sociopolitical context that would lead to their standardisation are often spoken in multilingual environments.

Western languages are for the most part spoken in areas where longstanding essentialising and prescriptive tendencies have created distinct language entities to the extent that it is possible to separate their lexica and grammars and to describe convergences between two languages to a large extent in terms of interferences, code-switching, and the like. Written sources often allow to establish the etymologies of lexical items of questionable origin and facilitate the tracing of grammatical change and the localisation of its source patterns. In areas of extensive societal multilingualism, pervasive language contact renders many of the axiomatic concepts in the baggage of a descriptive linguist problematic, if not useless altogether, resulting in a number of challenging questions to be answered: What are the 'languages' spoken in a given area, what motivates the assumption of languages or distinct codes as discrete entities in the first place, and how can their variation be measured? How can extensive but stable multilingualism be distinguished from situations of language shift? How do different codes interact in the mind of multilingual speakers? What is a loanword, what code-switching, what a shared retention, what a mixed language? Who are representative speakers (and of what), in the light of the difficulty to apply the concepts of 'mother tongue', 'first' and 'second language' in these settings?

It is somewhat ironic that field linguists are often forced to identify a language as an object of study prior to having the occasion to attempt at least an initial answer to some of these questions. Partly, this dilemma stems from essentialising language ideologies (Dobrin et al. 2007; Duchêne and Heller 2007; Lüpke 2009; Nicolaï 2007a, Nicolaï 2007b) and partly, from the competition in obtaining funding to work on a language that results in its commodification (Dobrin et al. 2007; Duchêne and Heller 2007) so that seemingly clear-cut cases of languages with an ISO-code, an Ethnologue entry, a location that can be given in latitude and longitude, and an exact number of speakers are given preference over muddled and unknown language situation. This was the case of the research reported here, a pilot project of 10 weeks' duration to collect initial documentary data on "Baïnounk". Faced with a dauntingly complex multilingual situation, it became quickly evident that only a combination of sociolinguistic data on attitudes with the observation and analysis of linguistic practices not just of speakers of "Baïnounk" but of the other languages spoken in the area, complemented by an assessment of the available historical information, could provide the data necessary in order to grasp the meaning of this umbrella term. Such an endeavour requires long-term collaborative, and ideally interdisciplinary research. Here, only the very first steps towards this goal can be reported. While this article looks at the issue from an identity perspective, Cobbinah (this volume) inspects language contact in a closely related language from a lexical and structural point of view, thus offering a complementary perspective. Both perspectives will converge in ongoing and future research.

\subsection{Baïnounk as a language continuum: nomenclature and extension}

Baïnounk (or Bainouk, Baynunk, Banhum, Nyuun, Gunyuun, Guñuun to name but a few appellations) is the cover term for a cluster of related languages or dialects belonging to the Atlantic branch of the Niger-Congo language phylum. Figure 1 shows the classification of Atlantic languages according to Sapir (1971). Atlantic is one of the most contested branches of Niger-Congo (Childs 2004; Podzniakov 2007; Wilson 1989), and recent studies regard the Northern and Southern branches as independent offshoots of the Niger-Congo language phylum (Blench 2006; Childs 2010). Together with its closest relatives-Buy (Cobiana/Kobiana) and Cassanga/Kassanga - Baïnounk belongs to subgroup 3a of the Eastern Senegal Guinea languages. 
Figure 1: Genealogical classification of Atlantic according to Sapir (1971), with Banhum (Baïnounk) in bold face

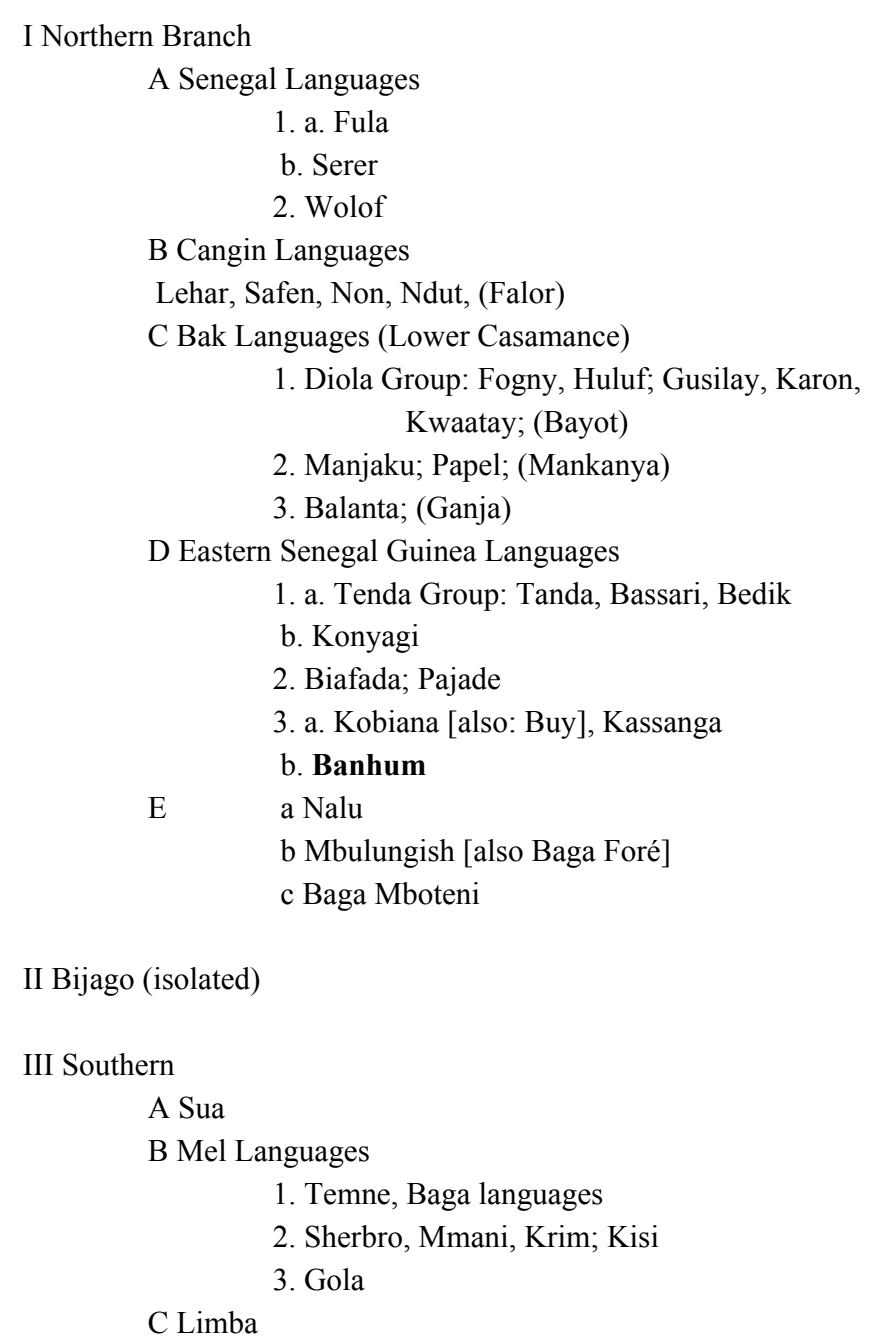

The different Baïnounk lects are spoken in the Casamance area of Senegal and, depending on how one draws the boundaries of the Baïnounk language as a whole, in the neighbouring countries Gambia and Guinea Bissau. Sauvageot (1973) presents a map based on fieldwork on Gunyaamolo in 1973 that shows the distributions of Baïnounk-speaking villages over the Casamance territory. 
Map 1: Baïnounk-speaking villages according to Sauvageot (1973)

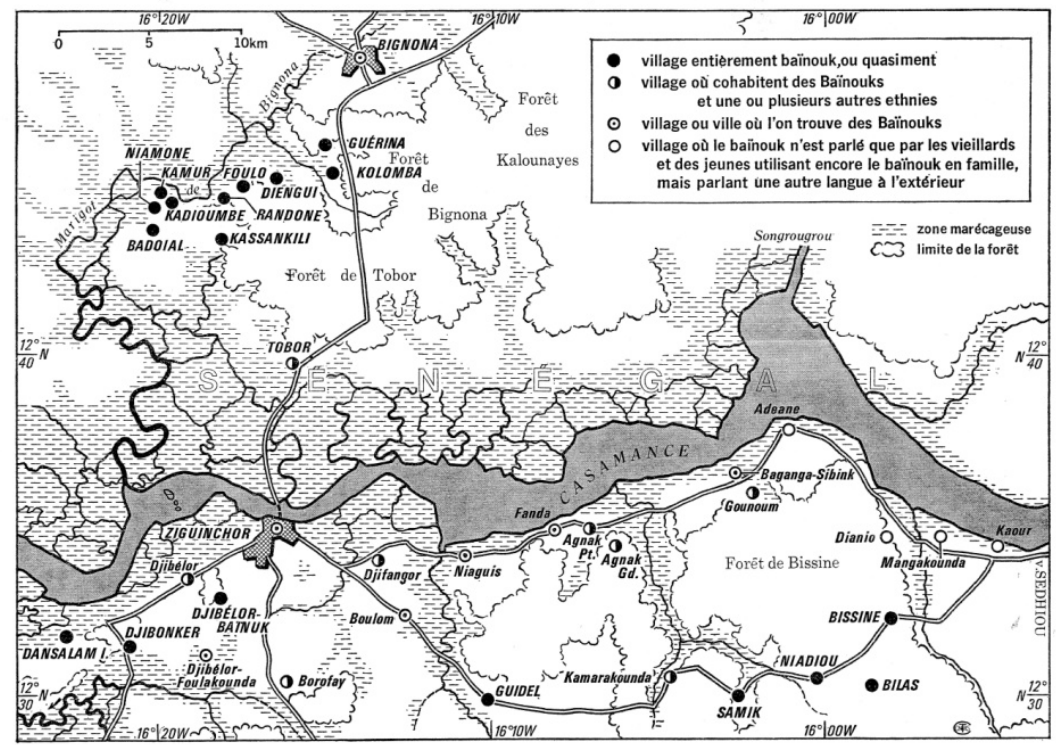

Recent fieldwork (Friederike Lüpke 2008, Alexander Cobbinah 2009/10 (see also Cobbinah, this volume)) shows that the map, although essentially still valid, needs to be partially redrawn. In the northern language area around Niamone, the number of villages dominated by speakers of Baïnounk has decreased. In the south-west, Baïnounk Gubaher is now only spoken in one village, Djibonker, with closely related varieties in Djifangor and Djibelor. No new data on the south-eastern Gujaher variety are available, but it is probable that the same trend is observable there.

The absence of a satisfactory amount of basic description contributes to the uncertainty regarding the internal structure of the cluster and its relationships to Buy and Kassanga. According to Sapir (1971), Banhum (in his use comprising the northern variety Gu-ñamolo described by Sauvageot, and the southern Gu-jaaxat variety described by Wilson) and Kobiana share $36 \%$ vocabulary out of a Swadesh 100-word list. Wilson (2007) indicates $74 \%$ of shared lexical percentages in a 100-item wordlist for Buy and Kassanga, but only $33 \%$ of cognates between these two languages and what he calls Banhum or Gujaaxər. Already Sapir (1971:61) notes: “A brief comparison of Sauvagoet's (1967) discussion of northern Banhum (Gu-ñamolo dialect) with Wilson's field-notes on the southern speech (Gu-jaaxat) makes clear considerable variation within the language itself". This is confirmed by the calculation of shared vocabulary of words from different Baïnounk varieties by Doneux (1990:87), based on word lists of varying size and quality for different lects by Bühnen. There, closely related varieties such as those of the neighbouring villages Niamone and Tobor and Djibonker and Djifangor respectively reach around $70 \%$; overall, the percentage of shared lexical items based on these inconclusive data is given as ca. $60-65 \%$. Furthermore, there is evidence for additional varieties that might for different reasons be included: In the view of Bühnen (1994), shared by the influential cultural organisation BOREPAB ${ }^{1}$, the language cluster consists of three main varieties - Gunyaamolo (spoken in and around Niamone and in the neighbouring country Gambia), Gubaher (spoken in Djibonker), and Gujaher (spoken in and around Samik). Speakers of Gubaher (who were visited in Djibonker in March 2008 and are in the focus of Cobbinah (this volume)) regard themselves as Baïnounk and their variety as a Baïnounk language, corroborating BOREPAB's opinion. Gubaher is the only Baïnounk

1 Bureau d'Organisation, de Recherche et d'Étude du Patrimoine Baïnounk, Bureau for the Organisation, Research and Studies of the Baïnounk Heritage founded around 1981. 
variety that has not received any attention from western linguists yet. All varieties are in turn reported to have different dialects.

\subsection{Speaker numbers and endangerment situation}

All Baïnounk varieties present strong a priori evidence for being endangered languages and have been analysed as such (de Lespinay 1987). While there are strong reasons that make a description and documentation of Baïnounk urgent-a persisting low-level civil war plaguing the area, important rural exodus and rapid climatic and cultural change, all resulting in depleting the rural homebases of speakers - it is impossible to predict the future of the languages in light of the limited information. The factors at play in possibly endangering Baïnounk in present-day Senegal are mainly of a socioeconomic nature and affect all rural communities, but of course have a much more dramatic impact on communities already of an extremely small size. Due to the possibilities of salaried employment and educational and economic advancement, there is considerable rural exodus, with the regional capital Ziguinchor and the national capital Dakar being the most important destinations. Until recently, men migrated to work as seasonal labourers during the dry season, when the agricultural activities are very reduced, and returned in the rainy season. Currently, the migrations are becoming more frequent and often permanent, and many villages see their male population between 20 and 50 years of age drastically reduced (with the exception of salaried civil servants often coming from other regions of the country and not speaking Baïnounk). In addition, it has become very lucrative for young women to migrate to cities in order to gain employment as domestic workers. Consequently, the villages are depleted of younger community members, whereas in the cities, important diasporas came into existence. It is hoped that it will be possible to consolidate existing data (see below) with newly collected information in order to identify trends in the development of speaker numbers, linguistic behaviour and attitudes.

Numbers of speakers and labels for Baïnounk varieties and assumptions on their relatedness are inconclusive and differ widely according to the source. De Lavergne de Tressan (1953) offers the number of 7219 speakers for the French territories and of 267 on Portuguese territory (present-day Guinea Bissau), based on colonial census data from 1950. Sauvageot (1987a) estimates speakers of all varieties as about 20000, without motivating this number. The Ethnologue (Gordon 2005) gives an estimated number of 5635 speakers for Gunyaamolo. A distinct Bainnounk language with the name Gunyuno is enumerated there with 8170 speakers, but it is unclear which variety is meant, since no clear indication of its location is given. For some speakers of Gunyaamolo, the term Guñun refers to the language as a whole. ${ }^{2}$ It is not impossible that the Ethnologue label Baïnounk Gunyuno corresponds to Baïnounk Gubaher, but in that case the speaker numbers are not at all accurate, since Baïnounk Gubaher is presently spoken only in the villages of Djibonker, by ca. 1000 speakers (Cobbinah, this volume). A third Baïnounk language listed by the Ethnologue is BaïnounkSamik (1685 speakers), which probably corresponds to Baïnounk Gujaher, since this variety is spoken in and around the village of Samik. The Ethnologue speaker numbers seem very high, and their provenance as well as the justification of the nomenclature used is unclear. The diaspora in Dakar comprises ca. 400 people, some of them speakers of different Baïnounk varieties (Alexander Cobinah, p.c.). In the following, I will use the labels used by BOREPAB since they correspond to the self-reference terms used by the respective speech communities.

\footnotetext{
${ }^{2}$ The term Baïnounk probably wasn't a self-reference term originally but is likely to stem from the Mandinka word bainuke for the Gunyun-speaking population of Casamance, since -ke is a locative suffix in Mandinka. Today, Baïnou(n)k, as it is spelled in the official language of Senegal, French, is the most frequently used term to refer to the language as a whole and the one adopted by BOREPAB. Therefore, it is the one retained here.
} 


\subsection{Previous and ongoing research}

No Baïnounk variety has been comprehensively described or documented. Some linguistic information is available for two of the three main varieties:

For Gujaaxer, a number of wordlists and information on (mainly nominal) morphosyntax from a comparative point of view is present in Doneux's (1990) classification of the related language Buy, and in Wilson (2007)). Only Baïnounk Gunyaamolo has received some deeper linguistic attention to date, with publications on different aspects of its grammar (Sauvageot 1967, 1973, 1975, 1987a, 1987b, 2004b). In addition to ongoing research on Baïnounk Gubaher by Alexander Cobbinah at SOAS, Baïnounk Gunyaamolo by the author and by Sokhna Bao-Diop at the CNRS-LLACAN in Paris, there is also important research activity, mainly on Baïnounk Gunyaamolo, but recently also on the other varieties, at the University Cheikh Anta Diop in Dakar. A number of MA, MPhil and PhD theses, two on nominal classification alone in Baïnounk Gunyaamolo, have been defended there. Unfortunately, this research is entirely cut off from linguistic sources and ignores the published research on Baïnounk and related languages, and even earlier Senegalese theses. So, for instance, the two theses mentioned above each claim to be the first account of the Baïnounk Gunyaamolo noun class system. From October 2010, a collaborative research project funded by the DoBeS programme of the German VW foundation involving Friederike Lüpke and Alexander Cobbinah will unite linguists, an ethnobotanist and an ethnoarchaeologist to work on language and cultural practices in three Baïnounk varieties.

\section{Possible ways of defining Baïnounk}

\subsection{Historical aspects}

According to historical research (Bühnen 1992, 1994; de Lespinay 1987, 1996, 1997), the Baïnounk and the related, almost extinct, Kasanga are to be regarded as the indigenous people of Casamance. In this sense, Baïnounk would minimally be a cover term for the first known inhabitants of the area, without claims regarding a cultural/linguistic/ethnic identity, however defined. For centuries, these autochthonous populations received settlers of different ethnolinguistic groups and, adhering to elaborate landlord-stranger relationships, gave them ground to cultivate. This custom, further complicated by wars with neighbouring groups, encouraged further influx of populations speaking Joola languages and Mandinka and resulted not only in a drastic shrinking/reduction of the Baïnounk territory but also in the linguistic assimilation of the majority of Baïnounk speakers. The Baïnounk peoples, like the different Joola groups, are not organised in larger state formations but constitute relatively egalitarian societies grouped in different patrilinear lineages, sometimes with a king as their head, but without a central government or overarching structure. In the east, this made them vulnerable to the domination of the Mandinka, who had the advantage of a unified and strongly stratified social structure. Regarding the cohabitation with the Joola, who like the Baïnounk lack centralised political and religious structures, it remains unclear what factors favoured a domination of the Joola, but Bühnen draws a convincing picture of regression and assimilation of the Baïnounk. In addition, speakers of Baïnounk were among the most affected victims of the slave trade (Rodney 1969), which further contributed to their decimation. As a consequence, today, the Baïnounk languages are only spoken in isolated pockets by small communities which are not in contact with each other in rural settings.

\section{2. 'Ethnic' aspects}

In spite of the fragmented nature of territorial and linguistic unity, the Baïnounk are developing an ethnic identity today. It is tempting to see this process of nation-building as analogous to similar tendencies among the Joola groups. Anthropologists and art historians (among others Mark 1992, 1997, 2002; Thomas 1959) have described how the people speaking this group of closely related Bak languages were first categorised under the label 
Joola by colonial administrators in the $19^{\text {th }}$ century, a common practice in colonial Africa ( $c f$. Amselle, 1990). An equally plausible scenario, and the one developed by Bühnen (1994) is that BOREPAB has been a decisive agent in creating and promoting a shared Baïnounk variety. Founded in the early 1980s, this organisation aims to familiarise the Baïnounk of different areas with each other with the goal of rediscovering their history. In the early years, many activities of BOREPAB focussed on oral history, and Bühnen convincingly argues that as a result, there has been a strong convergence of historical accounts in terms of protagonists, motives, places, etc. Possibly, the Joola model and the BOREPAB-style activism (in turn fuelled by missionary activities, see 2.4 below) reinforced each other. The consequence is that people of different religious affiliations, settlement structures, and social structures came to emphasise aspects that unite them (for instance sacred groves, mask dances, initiation rites, shrines) over those that separate them. In the process they chose a number of traditions as emblematic whose 'ethnic' affiliation is doubtful, given that they are attested throughout Casamance. $^{3}$

\subsection{Linguistic aspects}

Due to the long cohabitation with other ethnolinguistic groups, the Baïnounk language area is characterised by a complex multilingual situation, and the different varieties are partly in contact with different languages. Depending on their location, rural speakers use two distinct varieties of the Atlantic language cluster Joola (Joola Fogny and Joola Kasa), sometimes additional Joola languages (see Cobbinah, this volume), and/or the Mande language Mandinka. All of them are also fluent to some extent in the national lingua franca Wolof, an Atlantic language, and many speak the official language French. In addition, a Portuguese-based Creole has left traces in the language. As a consequence, the Baïnounk communities exhibit extensive multilingualism as a systematic trait not just of individuals, but of entire speech communities. High linguistic diversity and societal multilingualism is characteristic of the entire Casamance. Interestingly though, speakers of Baïnounk are not generally multilingual in more than one Baïnounk variety. Despite the fact that the Baïnounk languages are closely related and form a distinct cluster within the group of Eastern Senegal Guinea languages, this close relationship is not matched by synchronic proximity and linguistic interaction of speakers. The details of the multilingual profile of one Bainnounk community will be presented in 3 .

\subsection{Language activism and literacy campaigns}

Most African countries only use the official languages for formal education and only major languages in informal literacy. With the exception of two villages of the Gunyaamolo variety of Baïnounk, in which missionaries ran literacy classes for a number of years, this finding is true for all remaining Baïnounk language areas, comprising approximately twenty villages. Despite this limited scope it is worthwhile pausing to look at the impact of the American missionaries of the New Tribes Mission (NTM) not only on literacy in Baïnounk Gunyaamolo but on the emergence of an overarching Baïnounk identity in general. NTM missionaries have been active in the Baïnounk Gunyaamolo language area for more than 30 years, with a permanent presence in the Gunyaamolo village Niamone ${ }^{4}$. There and in the neighbouring village Diengué, literacy campaigns were run for a number of years but stopped when a generation of missionaries left a number of years ago, since the newcomers still have to gain sufficient fluency in the language. NTM has a strong emphasis on literacy, since it relies on the translation of the bible and a literate audience able to read it. The preparatory

\footnotetext{
${ }^{3}$ A case in point are the Kumpo mask dances, seen by most present-day Baïnounk as an emblem of Baïnouk-identity, but probably quite recently introduced in the entire Casamance area and definitely attested for Joola and Mandinka (de Jong 1999, Mark 1992).

${ }^{4}$ Since the main linguistic efforts (Sauvageot 1967, 1973, 1975, 1987a,1987b, 2004a, 2004b) are also concentrated on this variety, an overrepresentation of Gunyaamolo has been criticised by BOREPAB ever since.
} 
linguistic and literacy work of the missionaries fell on fertile ground with BOREPAB, who had been lobbying since the 1980s for the preservation of Baïnounk cultural and linguistic heritage. Figure 2 illustrates BOREPAB cultural activism while at the same time illustrating the missing linguistic unity of the Baïnounk: it shows a man wearing a T-shirt with the BOREPAB logo and two typical Casamance masks, plus the slogans 'Baynunk community of Senegal' and 'Cultural identity' in French.

Figure 2: Man in Niamone wearing a BOREPAB T-shirt (Niamone, 2008)

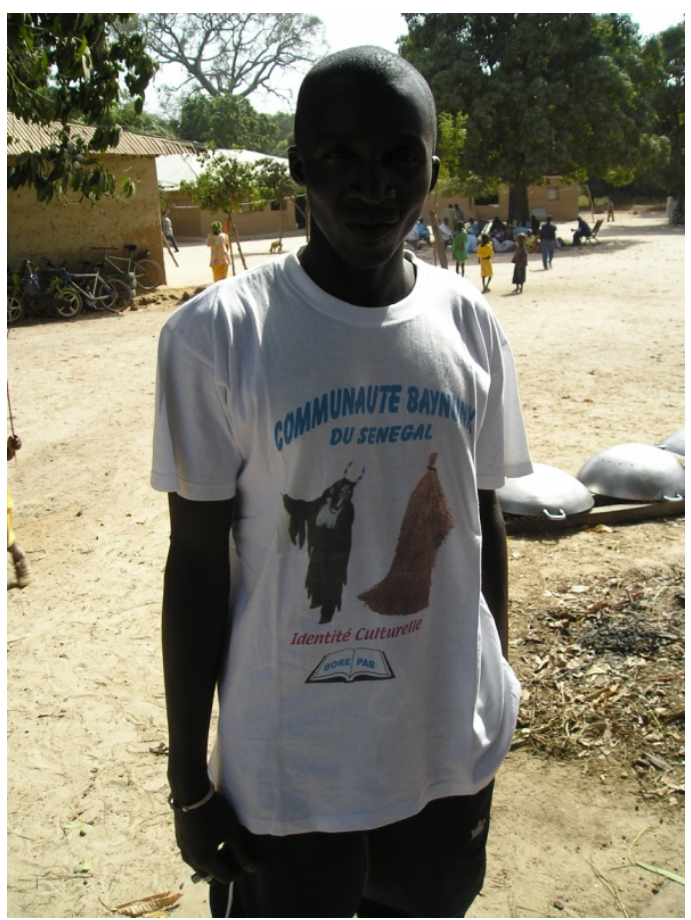

Figure 3: BOREPAB flyer from 1982

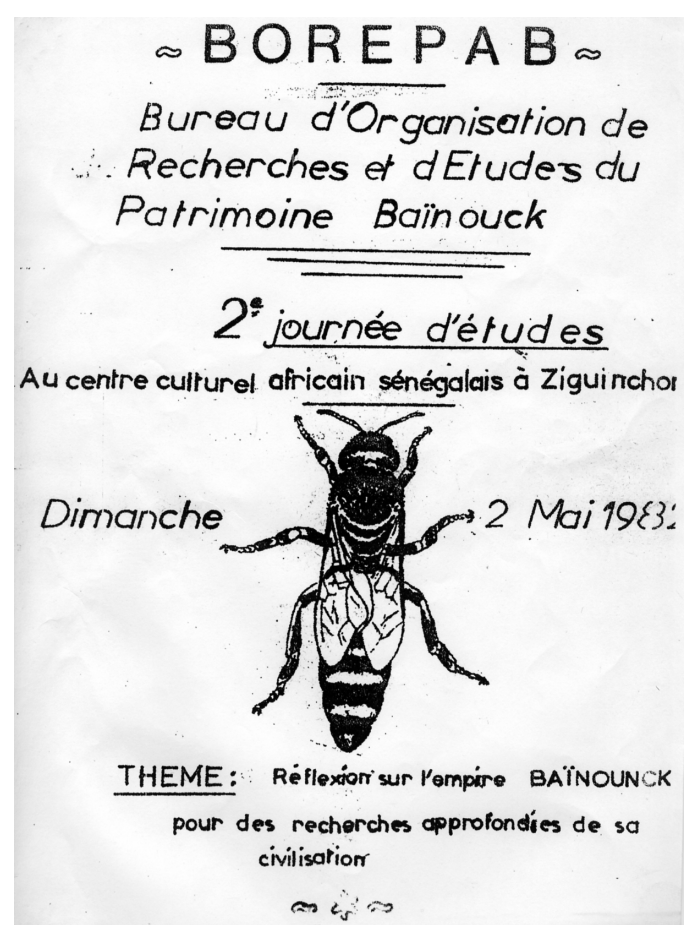

It is very plausible that the presence of the American missionaries has introduced BOREPAB members to discourses of language death from early on, as an awareness of global language endangerment is highly unusual for this area of Africa (see figure 4). 


\section{Figure 4: BOREPAB flyers explaining language death \\ PROCESSUS DE DISPARITION D'UNE LANGUE \\ LE DEVOIR DE PRESERVER, QUESTION DE VOLONTE}

\author{
LES LANGUES FRAGILISEES \\ Dans la famille, les enfants ne la parlent plus, mais que le père et la \\ mère connaissent et pratiquent la langue.

\section{LES LANGUES MENACEES OU EN VOIE} \\ D'EXTINCTION \\ Seules les générations des grands- parents, parlent couramment. Ces \\ vieilles personnes qui sont les seul s locuteurs, se comp tent et qu'elles \\ ne trouvent pl us d'inter locuteurs (fils et petits fils etc.) \\ Les mots ont glissé dans l'oubli, faute d'avoir été prononcés pendant \\ des années

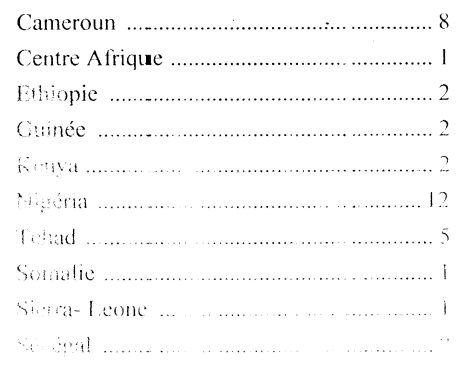

BOREPAB

\author{
- Une langue peut disparaitre, sans que le groupe ethnique \\ ait disparu. \\ $>$ Une langue meurt parce que son groupe cesse de la \\ pratiquer. \\ > Lors qu'une langue disparait, c'est une série \\ d'expériences individuelles ou des modes de vie collectifs qui \\ s'efface. \\ - La survie ou la mort d'une langue se situe à deux \\ niveaux : \\ Au sein de la famille; les enfants sont privés de parler la \\ langue, par négligence des parents, à cause de \\ l'environnement ou le chøix des couples mixtes. \\ Le choix des décideurs publics accordant un statut officiel à \\ un nombre réduit de langues au détriment d'autres laissées en \\ rade. \\ - Plus une langue est valorisée politiquement, plus elle a \\ la chance d'être écoutée à la radio- télévision et dans les \\ relations commerciales \\ BC REAU DE RECHERCHE ET D'ETUDE SUR LE \\ PATRIMOINE BAYNUNK
}

\section{BOREPAB}

NTM and BOREPAB formed an alliance in order to achieve the recognition of Bainounk as a national language of Senegal, a status reached in 2005. This status is conditional on 'codification', which means the existence of an alphabet and some linguistic standardisation. While the missionaries in their work excluded all the other Baïnounk languages, BOREPAB has been assuming an annexing stance with respect to the internal diversity of the language cluster. The association went as far as integrating Buy (Cobiana), a language closely related but without any mutual intelligibility with Baïnounk languages, into the Baïnounk cluster. While the immediate motivation for this extension may have been the urge to gain more political weight by creating a larger speech community, it also can be traced back to highlighting aspects of a shared history whose importance outweighs linguistic distance. The missionaries' Gunyaamolo alphabet, with few adaptations to the official alphabet for national languages of Senegal, is the main output of the codification. As for standardisation, this consists of a list of correspondences for some lexemes and morphemes and a short text given in the three main recognised varieties, with a translation into French, which is reproduced in figure 5. 
Figure 5: Text in the three main Baïnounk varieties published by BOREPAB as one of the documents for the standardisation of the language

it,

\section{VI- TEXTE D'ILLUSTRATION}

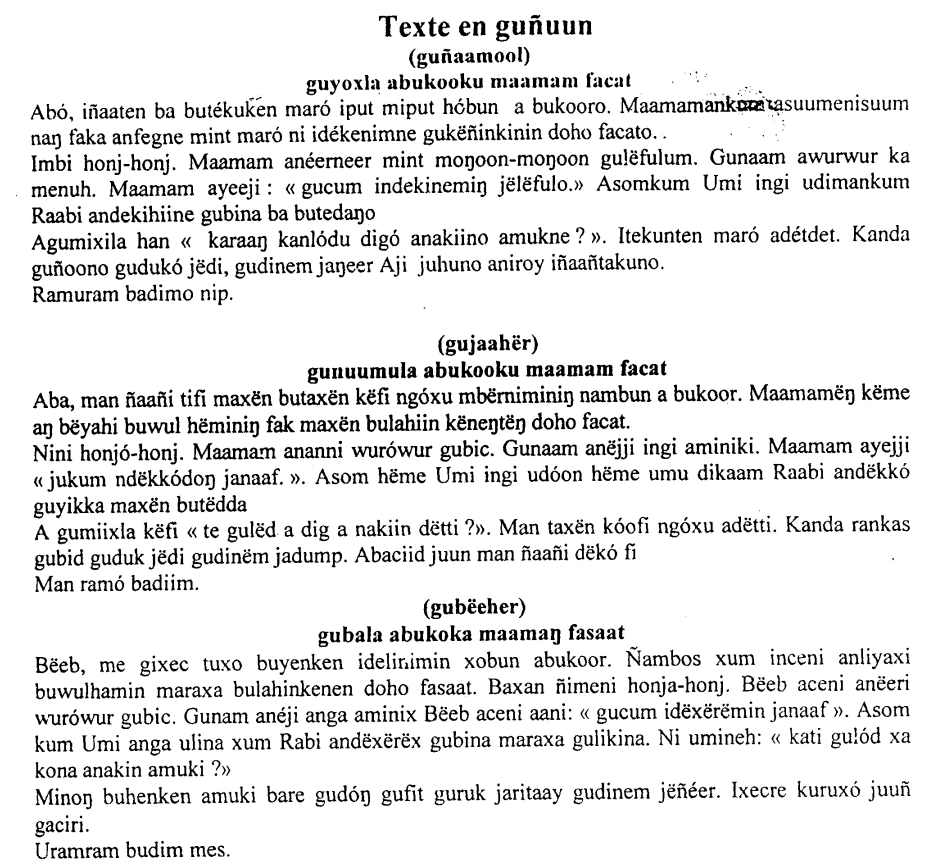

Traduction en français

En vacance chez grand père au village

Papa, je t'écris pour t'informer que nous sommes bien arrivés au village. Mes grands-parents Papa, je tecris pour tinformer que nous sommes bien arrives au village. Mes grands-parents sont contents de nous revoir parce que nous allons les aider dans les travaux champetres. Tout se
passe bien. Grand-père a donné à chacun un " kadiandu ». Le mien est long et lourd. Grand-père a dit : «demain nous irons cultiver ». ma tante Oumy et ma sœur Raby iront chercher du bois pour la cuisine.

A ta question: «est-ce que la construction de la deuxième maison est terminée ? ».Je te fais savoir que c'est fini mais une partie du toit est en paille et l'autre en feuilles de rônier. Je t'écrirai à la fin du mois.

Mes salutations à toute la famille.

The different Baïnounk versions of the text illustrate the considerable linguistic distance between the varieties. In light of this diversity and of the absence of resources, the official recognition of Baïnounk has had no practical consequences so far, and communication within BOREPAB as well as public activities of the association are still taking place in French (see also figures 2 and 3 above).

\section{Complex identities: a case study}

According to speakers of Baïnounk themselves and confirmed by my observations, multilingualism is not perceived as a threat. The majority of Baïnounk speakers affirm that the long-established multilingualism in Joola languages and Mandinka is part of their identity, priding themselves on being able to communicate with all major linguistic groups in Casamance and beyond. The positive values associated with multilingualism are also stressed by Cobbinah (this volume) for the Baïnounk Gubaher community.

In order to gain a first understanding of the patterns of multilingual language use and the precise attitudes towards the different languages, a pilot sociolinguistic study was carried out between January and April 2008 in two villages of the Gunyaamolo variety of Baïnounk. There 
are plans to increase the sample size and replicate the study in the different Baïnounk language areas. The study combines the collection of demographic information with the investigation of attitudes towards the languages present in the environment.

\subsection{Method and sample}

In Niamone and the neighbouring village Diengué, a total of $32^{5}$ Gunyaamolo speakers, 16 from each village, participated in the following tasks:

- An interview collecting basic demographic data and information on languages spoken and written by the participants and to their immediate family members;

- A questionnaire containing ideologically charged statements about language and identity collecting information on attitudes towards languages with which the participants could agree or disagree;

- A questionnaire eliciting which languages were used in a number of different domains such as the home, field, market, health centre, government office, mosque; etc.

- A questionnaire eliciting the typical linguistic repertoires for old and young men and women.

The questionnaires and statements were prepared in French after consultation with four main research assistants. These assistants also participated in determining the structure of the stratified sample and collected the data for the study by translating the questionnaires into Baïnounk or conducting the interviews in French. ${ }^{6}$

From each village, 8 male and 8 female consultants took part in the study. The sample was further stratified according to age groups suggested by the local research assistants. The participants represent the following age groups: older than 46 years in 2008 (the last generation not having a chance to attend school, as the local school was built in the late sixties); between 31 and 45 years of age in 2008; between 19 and 30 years of age; and between 14 and 18 years of age in 2008. To summarise, the structure of the sample is as follows:

Table 1: Structure of the sample for the sociolinguistic study according to age group, gender and village $(n=32)$

\begin{tabular}{|l|l|l|}
\hline Age & Niamone & Diengue \\
\hline older than 46 & 2 male, 2 female & 2 male, 2 female \\
\hline $31-45$ years & 2 male, 2 female & 2 male, 2 female \\
\hline $19-30$ years & 2 male, 2 female & 2 male, 2 female \\
\hline $14-18$ years & 2 male, 2 female & 2 male, 2 female \\
\hline
\end{tabular}

All but three participants $(90.6 \%)$ were born into Muslim families and are practising Muslims; $3(9.4 \%)$ converted to Islam. The first language of the mother of $85.7 \%$ of the participants is Gunyaamolo, that of the remaining $14.3 \%$ is Mandinka. All the participants' fathers have Gunyaamolo as their first language. $18.8 \%$ of the participants are sedentary; $31.3 \%$ have temporarily migrated to Dakar; $6.3 \%$ to the closest town Bignona, and the remainder have

\footnotetext{
${ }^{5}$ This number may appear low to sociolinguists studying variation. They are reminded here that the case study was only one aspect of a larger, documentary linguistic, project, and that the resources for this study, in terms of manpower and time was very limited. It is planned to extend the sample both in terms of participant numbers and covered language areas, in the near future.

${ }^{6}$ It became clear in the analysis, that the identity of the interviewer had an impact on the results for the attitude questionnaire and for the elicitation of typical repertoires. This impact will be discussed in detail in the section on perceived repertoires, in section 3.3.
} 
lived in different areas of Senegal for some time or even migrated abroad. The participants had the following levels of education:

Table 2: Structure of the sample in terms of level of education in percent $(n=32)$

\begin{tabular}{|l|l|}
\hline Years spent in formal education & Percent \\
\hline 0 & 16.1 \\
\hline 3 & 3.2 \\
\hline 4 & 3.2 \\
\hline 5 & 3.2 \\
\hline 6 & 32.3 \\
\hline 8 & 3.2 \\
\hline 9 & 6.5 \\
\hline 10 & 9.7 \\
\hline 11 & 6.5 \\
\hline 13 & 6.5 \\
\hline 14 & 3.2 \\
\hline 15 & 6.5 \\
\hline
\end{tabular}

\subsection{Overall linguistic profile}

In terms of languages spoken, the following global picture emerges:

Table 3: Languages spoken in percent $(n=32)$

\begin{tabular}{|c|c|}
\hline Language & Spoken by percent \\
\hline Baïnounk Gunyaamolo & 100 \\
\hline Wolof & 90.6 \\
\hline Joola Kujamat $^{7}$ & 87.5 \\
\hline French & 87.5 \\
\hline Mandinka & 62.5 \\
\hline Creole & 0 \\
\hline
\end{tabular}

Differentiated according to domain of language use, complementary and overlapping domains for these languages emerge:

Table 4: Languages spoken in different domains in percent $(n=32)$

\begin{tabular}{|l|l|l|l|l|l|}
\hline Domain & Baïnounk & Joola Kujamat & Mandinka & Wolof & French \\
\hline Home & 96.9 & 0 & 6.3 & 3.1 & 6.3 \\
\hline Field & 96.9 & 3.1 & 3.1 & 6.3 & 3.1 \\
\hline Market & 90.6 & 87.5 & 59.4 & 84.4 & 68.8 \\
\hline $\begin{array}{l}\text { Health } \\
\text { centre }\end{array}$ & 90.6 & 71.9 & 53.1 & 84.4 & 71.9 \\
\hline $\begin{array}{l}\text { Government } \\
\text { office }\end{array}$ & 34.4 & 21.9 & 15.6 & 37.5 & 84.4 \\
\hline Mosque & 96.9 & 25 & 25 & 18.8 & 15.6 \\
\hline $\begin{array}{l}\text { Trip } \\
\text { village- } \\
\text { Ziguinchor }\end{array}$ & 90.6 & 62.5 & 40.6 & 75 & 46.9 \\
\hline $\begin{array}{l}\text { Primary } \\
\text { school }\end{array}$ & 34.4 & 15.6 & 3.1 & 25 & 84.4 \\
\hline
\end{tabular}

\footnotetext{
${ }^{7}$ Joola Kujamat is the Joola term for the Joola variety spoken in Bignona and surroundings, also referred to as Joola Fogny. Henceforth, whenever I refer to "Joola" in tables and text, it is Joola Kujamat/Fogny that is meant.
} 
Changing perspective and investigating how all the attested uses of a language are distributed over domains, dominant uses for languages become visible and are highlighted in bold face in table 5 below.

Table 5: Domains and languages spoken in them in percent $(n=5)$ [check]

\begin{tabular}{|l|l|l|l|l|l|l|l|l|}
\hline Language & Home & Field & Market & $\begin{array}{l}\text { Health } \\
\text { centre }\end{array}$ & $\begin{array}{l}\text { Govern- } \\
\text { ment } \\
\text { office }\end{array}$ & Mosque & Trip & $\begin{array}{l}\text { Primary } \\
\text { school }\end{array}$ \\
\hline Baïnounk & $\mathbf{1 5 . 3}$ & $\mathbf{1 5 . 3}$ & $\mathbf{1 4 . 4}$ & $\mathbf{1 4 . 4}$ & 5.4 & $\mathbf{1 5 . 3}$ & $\mathbf{1 4 . 4}$ & 5.4 \\
\hline $\begin{array}{l}\text { Joola } \\
\text { Kujamat }\end{array}$ & 0 & 1.1 & $\mathbf{3 0 . 4}$ & $\mathbf{2 5}$ & 7.6 & 8.7 & $\mathbf{2 1 . 7}$ & 5.4 \\
\hline Mandinka & 3 & 1.5 & $\mathbf{2 8 . 8}$ & $\mathbf{2 5 . 8}$ & 7.6 & 12.1 & $\mathbf{1 9 . 7}$ & 1.5 \\
\hline Wolof & 0.9 & 1.9 & $\mathbf{2 5 . 2}$ & $\mathbf{2 5 . 2}$ & 11.2 & 5.6 & $\mathbf{2 2 . 4}$ & 7.5 \\
\hline French & 1.6 & 0.8 & $\mathbf{1 8}$ & $\mathbf{1 8 . 9}$ & $\mathbf{2 2 . 1}$ & 4.1 & 12.3 & $\mathbf{2 2 . 1}$ \\
\hline
\end{tabular}

The use of Baïnounk is evenly distributed over domains associated with the home, the fields, the market in Ziguinchor (where all the Baïnounk women selling crops travel together once a week), the health centre, the mosque and the trip to town. Only in the home context is it the principal language used. In the fields, at the market, at the health centre and travelling to town Baïnounk is surpassed by Joola, Mandinka and Wolof, which all compete for these contexts. French is also attested in all these domains, but its main contexts are the government office and the primary school.

When extended to languages used in writing, the patterns of language use change considerably and look as follows:

Table 6: Languages written in percent $(n=32)^{8}$

\begin{tabular}{|l|l|}
\hline Language & Written by percent \\
\hline Gunyaamolo & 21.9 \\
\hline Wolof & 9.4 \\
\hline Joola Kujamat & 12.5 \\
\hline French & 78.5 \\
\hline Mandinka & 21.9 \\
\hline
\end{tabular}

Participants were also asked to identify the main language they speak with different relatives. The results are presented in table 7 below.

Table 7: Languages spoken with relatives in percent $(n=32)$

\begin{tabular}{|l|l|l|}
\hline Spoken with & Responses \\
\hline \multirow{2}{*}{ Mother } & Language & Percent \\
\hline Father & Gunyaamolo & 87.5 \\
\cline { 2 - 3 } & Mandinka & 14.3 \\
\hline Older relatives & Gunyaamolo & 100 \\
\hline Siblings & Gunyaamolo & 100 \\
\hline \multirow{2}{*}{ Spouse } & Gunyaamolo & 100 \\
\hline & Gunyaamolo & 96.4 \\
\cline { 2 - 3 } & Mandinka & 3.6 \\
\hline
\end{tabular}

\footnotetext{
${ }^{8}$ The percentages above refer to writing in the Latin script. Although writing in Arabic letters for Arabic and African languages (so-called Ajami writing) exists in Senegal and is attested in the area for Mandinka, only one participant in the sociolinguistic study speaks and writes Arabic and is able to write Gunyaamolo, Wolof, Joola and Mandinka on an ad-hoc basis in Arabic letters.
} 


\begin{tabular}{|l|l|l|}
\hline Children & Gunyaamolo & 82.1 \\
\cline { 2 - 3 } & $\begin{array}{l}\text { Gunyaamolo and } \\
\text { Wolof }\end{array}$ & 7.1 \\
\cline { 2 - 3 } & $\begin{array}{l}\text { Gunyaamolo and } \\
\text { Mandinka } 3.6\end{array}$ \\
\cline { 2 - 3 } & $\begin{array}{l}\text { Gunyaamolo, Wolof, } \\
\text { Mandinka and Joola } \\
\text { Kujamat }\end{array}$ & \\
\hline
\end{tabular}

\subsection{Attitudes}

Turning to attitudes and values, this section investigates how the participants respond to charged statements regarding the roles of the different languages in their surrounding.

Table 8: Attitude statements and responses in percent $(n=32)$

\begin{tabular}{|c|c|c|}
\hline Statement & Agree & Disagree \\
\hline $\begin{array}{l}\text { "We should completely } \\
\text { abandon our mother tongue } \\
\text { and only speak Joola." }\end{array}$ & 0 & 100 \\
\hline $\begin{array}{l}\text { "We should completely } \\
\text { abandon our mother tongue } \\
\text { and only speak Mandinka." }\end{array}$ & 3.1 & 96.9 \\
\hline $\begin{array}{l}\text { "We should completely } \\
\text { abandon our mother tongue } \\
\text { and only speak Wolof." }\end{array}$ & 0 & 100 \\
\hline $\begin{array}{l}\text { "Children will learn better } \\
\text { how to read and write if } \\
\text { taught in their mother } \\
\text { tongue." }\end{array}$ & 96.9 & 3.1 \\
\hline $\begin{array}{l}\text { "There are enough } \\
\text { resources available to teach } \\
\text { children how to read and } \\
\text { write in their mother } \\
\text { tongue." }\end{array}$ & 21.8 & 78.2 \\
\hline $\begin{array}{l}\text { "Children should learn to } \\
\text { read and write in Joola." }\end{array}$ & 18.7 & 81.3 \\
\hline $\begin{array}{l}\text { "Children should learn to } \\
\text { read and write in } \\
\text { Mandinka." }\end{array}$ & 21.9 & 78.1 \\
\hline $\begin{array}{l}\text { "Children should learn to } \\
\text { read and write in Wolof." }\end{array}$ & 18.7 & 81.3 \\
\hline $\begin{array}{l}\text { Children should learn to } \\
\text { read and write in French." }\end{array}$ & 84.4 & 15.6 \\
\hline $\begin{array}{l}\text { "It is a gift to speak several } \\
\text { languages." }\end{array}$ & 96.9 & 3.1 \\
\hline $\begin{array}{l}\text { "Speaking Joola or } \\
\text { Mandinka makes us } \\
\text { abandon our customs and } \\
\text { traditions." }\end{array}$ & 15.6 & 84.4 \\
\hline $\begin{array}{l}\text { "I am proud because I know } \\
\text { my mother tongue." }\end{array}$ & 100 & 0 \\
\hline $\begin{array}{l}\text { "It would be good to know } \\
\text { how to write Baïnounk." }\end{array}$ & 100 & 0 \\
\hline
\end{tabular}




\begin{tabular}{|c|c|c|}
\hline Statement & Agree & Disagree \\
\hline $\begin{array}{l}\text { "We will always be true } \\
\text { Baïnounk, even if we don't } \\
\text { speak our mother tongue } \\
\text { anymore." }\end{array}$ & 46.9 & 53.1 \\
\hline $\begin{array}{l}\text { "The people of my } \\
\text { community will always } \\
\text { speak their native } \\
\text { language." }\end{array}$ & 100 & 0 \\
\hline $\begin{array}{l}\text { "We should contribute } \\
\text { money for the production of } \\
\text { books in the mother } \\
\text { tongue." }\end{array}$ & 100 & \\
\hline $\begin{array}{l}\text { "Government agents should } \\
\text { make a bigger effort to } \\
\text { speak to us in our mother } \\
\text { tongue." }\end{array}$ & 93.8 & 6.2 \\
\hline $\begin{array}{l}\text { "In church or mosque } \\
\text { meetings, we should always } \\
\text { use Joola, Mandinka, } \\
\text { Wolof, French or other } \\
\text { languages, rather than the } \\
\text { mother tongue." }\end{array}$ & 6.2 & 93.8 \\
\hline $\begin{array}{l}\text { In church or mosque } \\
\text { meetings, we should only } \\
\text { use Baïnounk." }\end{array}$ & 71.9 & 28.1 \\
\hline $\begin{array}{l}\text { "Mandinka is the language } \\
\text { of Islam." }\end{array}$ & 25 & 75 \\
\hline $\begin{array}{l}\text { "Islam is a threat to our } \\
\text { mother tongue." }\end{array}$ & 6.2 & 93.8 \\
\hline $\begin{array}{l}\text { "The fact of speaking } \\
\text { several languages threatens } \\
\text { our Baïnounk identity." }\end{array}$ & 21.9 & 78.1 \\
\hline $\begin{array}{l}\text { "It would not be useful to } \\
\text { write Baïnounk." }\end{array}$ & 31.2 & 68.8 \\
\hline
\end{tabular}

It emerges that an overwhelming majority is in favour of literacy skills in Baïnounk and acknowledges the usefulness of mother tongue literacy in Baïnounk for children. The only other language which is seen as useful in literacy by a majority is French, but approximately $20 \%$ of respondents agree that children should learn to read and write in Joola, Mandinka and Wolof. At the same time, the link between language proficiency and Baïnounk identity appears weak, as $47 \%$ agree with its importance while 53\% deny it. Yet, there is an absolute confidence in the future of Baïnounk, as evidenced through the unanimous agreement with the statement "The people of my community will always speak their native language". Multilingualism is not been seen as a threat by $78 \%$ of respondents, and the often invoked association of Mandinka with Islam (and its spread) is not borne out by the responses. This last finding seems particularly noteworthy in light of the fact that in the Gubaher community in Djibonker, the term u-manding 'Manding' is synonymous with 'Muslim' (Alexander Cobbinah, p.c.).

Turning to the perceived linguistic repertoires, it is here that the influence of the interviewers skews the answers. For one interviewer, "typical" was translated into the interviewee's own family members; i.e. he asked participants to imagine their grandmother, daughter, niece, etc. The others went for an abstraction that sometimes was understood as "ideal" rather than 
typical - in this case, two respondents indicated the old generation as being monolingual in Baïnounk, something that in reality does not occur.

Table 9: Perceived linguistic repertoires for typical young men, young women, old men, and old women in percent $(n=32)$

\begin{tabular}{|l|l|l|l|l|}
\hline & Person & Old man & Yoman \\
\hline $\begin{array}{l}\text { Language } \\
\text { spoken }\end{array}$ & Young man & Young woman & Old man & 96.9 \\
\hline Gunyaamolo & 100 & 100 & 100 & 68.8 \\
\hline $\begin{array}{l}\text { Joola } \\
\text { Kujamat }\end{array}$ & 78.1 & 68.8 & 71.9 & 3.1 \\
\hline Wolof & 81.3 & 78.1 & 15.6 & 31.3 \\
\hline Mandinka & 65.6 & 56.3 & 50 & 3.1 \\
\hline French & 81.3 & 59.4 & 12.5 & \\
\hline
\end{tabular}

To the extent that the percentages in table 9 are reliable, they confirm a change in multilingual pattern that comes out elsewhere: the drop in importance of Mandinka at the expense of Wolof, and of course, the increase of knowledge of French.

\subsection{Variation according to age group}

The findings of table 9 above are replicated when the answers of the demographic questionnaire pertaining to the linguistic repertoires are compared according to age group ${ }^{9}$ :

Table 10: Linguistic repertoire according to age group $(n=32)$

\begin{tabular}{|l|l|l|l|l|}
\hline $\begin{array}{l}\text { Language } \\
\text { spoken }\end{array}$ & $\mathbf{4 6}^{+}$ & $\mathbf{3 1 - 4 5}$ & $\mathbf{1 9 - 3 0}$ & $\mathbf{1 4 - 1 8}$ \\
\hline $\begin{array}{l}\text { Bainouk } \\
\text { Gunyaamolo }\end{array}$ & 100 & 100 & 100 & 100 \\
\hline Joola Kujamat & 100 & 100 & 87.5 & 62.5 \\
\hline Wolof & 75 & 100 & 100 & 87.5 \\
\hline Mandinka & 75 & 100 & 37.5 & 37.5 \\
\hline French & 62.5 & 87.5 & 100 & 100 \\
\hline
\end{tabular}

\subsection{Discussion}

The demographic profile of the Baïnounk communities of Niamone and Diengué shows a flexible multilingual profile in which the number of languages is kept more or less constant (under the assumption that Creole has lost influence since the islamisation of the two villages and that its function has been taken over by Wolof after independence), but their inventories change over time according to their functions, in line with Mufwene's ecology of language evolution (Mufwene 2001). 100\% of Baïnounk Gunyaamolo speakers over 46 years of age are proficient in a Joola language, $75 \%$ of them speak Mandinka, and $75 \%$ speak Wolof. Among the youngest generation interviewed, a clear shift to Wolof as a vehicular language is recognisable. Thus, among the 14-18 year olds only $62.5 \%$ speak Joola Fogny and 37.5\% speak Mandinka, the two most important linguae francae of Casamance. None of the Baïnounk Gunyaamolo speakers interviewed spoke Creole, the old vehicular language of interreligious communication and urban contexts (Juillard 1995). Rather, 87.5\% of young speakers claimed to speak Wolof, a significant increase of this language, which is rapidly turning into the de facto national language

\footnotetext{
${ }^{9}$ Because of the small overall sample size, the responses per age group were only 8 per group. Therefore, some reservations are in order and the sample size needs to be increased before it can be assumed that the percentages represent a robust trend.
} 
of Senegal (see also (McLaughlin 2009). The use of French, the official language of colonial inheritance has also risen from $62.5 \%$ among the older generation to $100 \%$ of the young generation. Nevertheless, it can be safely stated that French, unlike colonial languages in most endangerment contexts worldwide, is not the language posing the largest threat to Baïnounk. This is consistent with the picture of colonial languages throughout Africa (Batibo 2005; Brenzinger 1992, 1998). The use of French is limited to a number of clearly delimited contexts such as formal education and government offices. The language most present in the home context next to Baïnounk is Wolof, which confirms observations made in urban (Juillard 1995) and rural situations in Casamance (Sagna 2008). All interviewees in these villages are of the opinion that their language would survive in the rural speech communities, but do not attach too much importance to the maintenance of Baïnounk for identity purposes.

Only a fifth of the population has (mainly rudimentary) literacy skills in Baïnounk. Yet, 97\% of Baïnounk Gunyaamolo speakers consulted regard writing Baïnounk as positive, and believe that writing Baïnounk is instrumental in keeping the language alive. This attitude is not matched by practice, though, since only $22 \%$ participated in Gunyaamolo literacy classes while they were offered, and this is equal to the number of people having literacy skills in Mandinka $(22 \%)$. In fact, the introduction of Mandinka literacy classes in Diengué, through an NGO giving out sacks of rice and cans of oil as an incentive to participate, contributed to the failure of Baïnounk literacy classes there.

\section{Conclusion and outlook}

This paper presents a first attempt to grasp the complex linguistic and cultural identities in an extremely multilingual situation. Future research based on an extended sample and additional speech communities will reveal which of the findings of the pilot study reported here are idiosyncratic to two villages and which can be generalised to all Baïnounk communities. At the same time, the preliminary findings confirm my own observations of a community that prides itself on its capacity to speak all the languages in its environment (a skill also remarked upon by Bühnen 1994 and by Cobbinah, this volume), and whose survival as a linguistic group in situ is not really at risk, notwithstanding external factors that can have sudden and drastic effects in communities of a small size. In contrast, in discussions people stress their concerns about migration and the future of the language in the diasporas which continue to grow at the expense of the rural population. In addition to shifting numbers of speakers from villages to cities, the increased migration and attraction of Wolof as the language of the national elite also has repercussions on the multilingual profile of rural speakers. However, it seems premature to conclude that Wolof is gradually replacing Baïnounk in rural areas. More studies are required in order to understand what scope Wolof has in the interactions of the young speakers who are those who use it most, and whether it is just added to their repertoire in order to link them to youth culture (dominated by rap, hip hop and mbalax music in Wolof), or whether it actually substitutes another language.

As for literacy, regarded as a backbone of language maintenance efforts by BOREPAB and the NTM missionaries, it emerges as doubtful what scope it could have in the Baïnounk communities studied. Baïnounk is used in a locally very limited sphere, where oral communication prevails. Several other languages are already used in writing, and the preferences seem to be for French as the written language, despite positive attitudes to writing in Baïnounk. While it seems important to invest in an orthography for its sheer emblematic function, there should be no illusions about its practical use. On the contrary, the considerable engineering necessary in order to standardise, or rather, create a Baïnounk language appears to threaten the linguistic diversity of Baïnounk varieties without having a realistic chance of contributing to language maintenance. As is very common in the African context (Lüpke 2009; Mous 2003), communities remain very vital and achieve an astonishing level of multilingualism 
without any institutional support as long as they are spoken in intact rural environments. It is the threat to these environments, not the absence of resources or language activism that is significant in this case, as in many African minority languages.

Regarding the relevance of the findings for a better understanding of multilingualism and language contact in West Africa, it appears that the following points are important in order to guide further research on languages in this area:

- Descriptive and documentary efforts need to be preceded by sociolinguistic investigations that allow an assessment of the linguistic ecosystem on the ground and of the scope and functions for the different languages/varities/lects used where, when, and by whom.

- These investigations can guide linguistic research by providing crucial information on which genres and registers to collect in which variety and from which speakers, and on where to expect the most and where the least language contact.

- According to the multilingual profiles of individuals and 'communities', linguistic information on the languages other than the 'target language' needs to be systematically collected, and ideally be presented in a format facilitating comparative research.

This paper has presented a first step towards an understanding of the sociolinguistic context of one Baïnounk variety. Its results will be useful in selecting genres and registers for a detailed documentation and description, and for interpreting the presence of other codes in them. Only by thus assessing and analysing the full heterogeneity encountered in these contexts and by having the tools for interpreting it can the necessary construction of the homogenous and the emergence of the "linguistic" (Nicolaï 2007b) be achieved.

\section{References}

Amselle, Jean-Loup. 1990. Logiques métisses. Anthropologie de l'identité en Afrique et ailleurs. Paris: Payot.

Batibo, Herman. 2005. Language decline and death in Africa: causes, consequences and challenges. Clevedon: Multilingual Matters.

Blench, Roger. 2006. Archeology, language and the African past. Lanham, MD: AltaMira Press.

Brenzinger, Matthias (ed.). 1992. Language death. Factual and theoretical explorations with special reference to East Africa. vol. 64. Contributions to the sociology of language. Berlin - New York: Mouton de Gruyter.

Brenzinger, Matthias. 1998. Endangered languages in Africa. Köln: Rüdiger Köppe.

Bühnen, Stephan. 1992. Place Names as an Historical Source: An Introduction with Examples from Southern Senegambia and Germany. History in Africa 19:45-101.

Bühnen, Stephan. 1994. Geschichte der Bainunk und Kasanga, Fachbereich Geowissenschaften und Geographie, Justus-Liebig Universität Giessen: $\mathrm{PhD}$ thesis.

Childs, G. Tucker. 2004. The Atlantic and Mande groups of Niger-Congo: a study in contrasts, as study in interaction. Journal of West African Languages XXX:29-40.

Childs, G. Tucker. (2010). The Mande and Atlantic groups of Niger-Congo: prolonged contact with asymmetrical consequences. Journal of Language Contact THEMA 3:15-46

de Jong, Ferdinand. 1999. Trajectories of a Mask Performance: The Case of the Senegalese Kumpo Cahier d'études africaines 39:49-71.

Dobrin, Lise, Austin, Peter K. and Nathan, David 2007. Dying to be counted: commodification of endangered languages. In: Peter K. Austin, Oliver Bond and David Nathan. (eds.). Proceedings of Conference on Language Documentation and Linguistic Theory. London: School of Oriental and African Studies (SOAS). 
Doneux, Jean. 1990. La place de la langue buy dans le groupe atlantique de la famille kongokordofan. Thèse de doctorat. Faculté de Philosophie et Lettres, Université Libre de Bruxelles.

Duchêne, Alexandre, and Heller, Monica. 2007. Discourses of endangerment: sociolinguistics, globalization and social order. In: Alexandre Duchêne and Monica Heller. (eds.). Discourses of endangerment. Interest and ideology in the defense of languages. London - New York: Continuum.

Gordon, Raymond G. Jr. (ed.). 2005. Ethnologue: Languages of the World Dallas, Tex.: SIL International.

Juillard, Caroline. 1995. Sociolinguistique urbaine. La vie des langues à Ziguinchor (Sénégal). Paris: Presses du CNRS.

Lavergne de Tressan, Michel de. 1953. Inventaire linguistique de l'Afrique Occidentale Française et du Togo: Mémoires de l'IFAN. Dakar: Institut Français d'Afrique Noire (IFAN)

Lespinay, Charles de. 1987. La disparition de la langue baynunk : fin d'un peuple ou processus réversible?. Cahiers du C.R.A. 5:23-29. (Centre de recherches africaines).

Lespinay, Charles de. 1996. Autochtonie et droit foncier; l'existence contestée des Baynunk en Afrique de l'Ouest. Droit et Cultures 32:55-65.

Lespinay, Charles de. 1997. Un lexique bagnon-floupe de la fin du XVII ${ }^{\mathrm{e}}$ siècle: apport à l'histoire du peuplement de la Casamance. In: Gérard Gaillard. (éd.). Migrations anciennes et peuplement des côtes guinéennes. Paris: L'Harmattan, 193-213.

Lüpke, Friederike. 2009. At the margin - African endangered languages in the context of global endangerment discourses. African Research and Documentation 109:15-41.

Mark, Peter. 1992. The wild bull and sacred forest : forms, meaning, and change in Senegambian initiation masks. Cambridge - New York: Cambridge University Press.

Mark, Peter. 1997. Economic and religious change among the Diola of Boulouf, Casamance, 1890-1940 : trade, cash cropping and Islam in southwestern Senegal, University Microfilms, Thesis (Ph D ) Yale University, 1976.

Mark, Peter. 2002. "Portuguese" style and Luso-African identity : precolonial Senegambia, sixteenth-nineteenth centuries. Bloomington: Indiana University Press.

McLaughlin, Fiona. 2009. The ascent of Wolof as an urban vernacular and national lingua franca in Senegal. In: Cécile Vigouroux and Salikoko S Mufwene. (eds.). Globalization and language vitality: Perspectives from Africa. London: Continuum.

Mous, Maarten. 2003. Loss of Linguistic Diversity in Africa. In: Marc Janse and Sijmen Tol. (eds.). Language death and language maintenance: theoretical, practical and descriptive approaches. Amsterdam: John Benjamins, 157-170.

Mufwene, Salikoko S. 2001. The ecology of language evolution: Cambridge approaches to language contact. Cambridge, U.K., New York: Cambridge University Press.

Nicolaï, Robert. 2007a. Le contact des langues : point aveugle du 'linguistique'. Journal of Language Contact THEMA 1:1-10.

Nicolaï, Robert. 2007b. Contacts des langues et contact dans la langue : hétérogénéité, construction de l'homogène et émergence du 'linguistique'. Journal of Language Contact THEMA 1:198-221.

Podzniakov, Konstantin. 2007. Etudes atlantiques comparatives: questions de méthodologie. Paris: Mémoires de la Societé de Linguistique de Paris.

Rodney, Walter. 1969. Upper Guinea and the significance of the origins of Africans enslaved in the New World. The Journal of Negro History 54:327-345.

Sapir, J. David. 1971. West Atlantic. In: Thomas A. Sebeok. (ed.). Current trends in linguistics, Vol. 7: Linguistics in Sub-Saharan Africa. The Hague - Paris: Mouton, 45-112.

Sauvageot, Serge. 1967. Note sur la classification nominale en Baïnounk. In: Gabriel Manessy. (éd.). La classification nominale dans les langues négro-africaines. Paris: Éditions du Centre national de la Recherche Scientifique (CNRS), 225-236. 
Sauvageot, Serge. 1973. Une carte des villages Baïnounk de Casamance (Sénégal) établie lors d'une mission accomplie en 1973. In: Les langues dans le monde ancien et moderne: Afrique subsaharienne. Paris: Éditions du Centre national de la Recherche Scientifique (CNRS).

Sauvageot, Serge. 1975. La phrase rélative en wolof et en Baïnounk. In: Mélanges offerts à Emile Benveniste. Paris: Société de linguistique de Paris, 493-499.

Sauvageot, Serge. 1987a. La linguistique en tant que témoignage historique: le cas du baynunk. Cahiers $d u$ C.R.A. 5:17-22. (Centre de recherches africaines).

Sauvageot, Serge. 1987b. Esquisse du système verbal du Baïnounk. Paris: Centre national de la Recherche Scientifique (CNRS).

Sauvageot, Serge. 2004a. De quelques procédés de mise en relief en baynuyk. In: Elisabeth Motte-Florac, Gladys Guarisma et Jacqueline M. C. Thomas. (éds.). Du terrain au cognitif : linguistique, ethnolinguistique, ethnosciences : À Jacqueline M.C. Thomas,. Leuven - Dudley, MA: Peeters, 26-41.

Sauvageot, Serge. 2004b. De quelques marqueurs syntaxiques ou affixes de voix en baynunk. In: Elisabeth Motte-Florac and Gladys Guarisma. (éds.). Du terrain au cognitif. Leuven: Peeters.

Thomas, Louis-Vincent. 1959. Les Diola. Essai d'analyse fonctionnelle sur une population de Basse-Casamance. Dakar: Institut Français d'Afrique Noire (IFAN).

Wilson, William André Auquier. 1989. Atlantic. In: John Bendor-Samuel. (ed.). The NigerCongo languages. New York - London: Lanham, 81-104.

Wilson, William André Auquier. 2007. Guinea languages of the Atlantic group. Description and internal classification. Frankfurt am Main: Peter Lang. 